\title{
Androgen receptor expression in a Sri Lankan patient cohort with early breast carcinoma
}

\author{
Harshima Disvini Wijesinghe ${ }^{1 *}$ D, Gayani Kokila Wijesinghe ${ }^{1}$, Zahara Mansoor', Sanjeev Vigneshwara', \\ Janakie Fernando², Dehan Gunasekera ${ }^{3}$ and Menaka Dilani Samarawickrama Lokuhetty ${ }^{1}$
}

\begin{abstract}
Background: Androgen receptor (AR) expression is emerging as a prognostic biomarker in breast carcinoma (BCa). The study aimed to determine the prevalence of AR expression by immunohistochemical analysis among a cohort of Sri Lankan women with early BCa and to evaluate its association with clinicopathological features including immunohistochemical molecular subtype and early survival.

Method: We studied the clinical and pathological features and immunohistochemical profile of 141 women undergoing primary surgery for early BCa, followed by standard adjuvant therapy. AR status was assessed by immunohistochemistry in all cases. Overall survival (OS) and disease-free survival (DFS) was determined. The relationship between AR expression and clinical and pathological parameters and immunohistochemical molecular subtype was analyzed using Student $T$ test and chi-square tests. Cox regression analysis was used to analyze the prognostic impact of AR expression.

Results: AR expression was seen in $40.8 \%(95 \% \mathrm{Cl} 33.10-49.07 \%)$ of the BCa study cohort. None of the clinical data studied showed a significant association with the AR status $(p>0.05)$. Ductal carcinoma in situ $(p=0.003)$, oestrogen receptor (ER) $(p=0.001)$ and progesterone receptor (PR) $(p=0.001)$ positivity and luminal IHC molecular subtype $(p=0.016)$ were significantly associated with AR-positive status. AR-negative status was significantly associated with tumour necrosis $>50 \%(p=0.031)$, moderate to extensive lymphocytic infiltrate at the tumour $\operatorname{margin}(p=0.025)$ and basal triple negative breast carcinoma $(p=0.016)$.

The mean duration of patient follow-up was $46.70(95 \% \mathrm{Cl} 46.495-46.905)$ months (3.89 years). On univariate analysis, AR-positivity was associated with better OS among ER-positive tumours $(p=0.047)$, specifically in postmenopausal women $(p=0.030)$. In ER-negative tumours, AR positivity was associated with worse DFS $(p=0.036)$. On multivariate analysis, TNM stage and ER/AR status were predictive of survival. ER-positive/AR-positive (ER+/AR+) tumours demonstrated better OS than ER-positive/AR-negative (ER+/AR-) tumours $(p=0.015)$. ER-negative/AR-positive (ER -/AR+) tumours ( $p=0.014$ ) had a worse DFS than ER-negative/AR-negative (ER-/AR-) tumours.

(Continued on next page)
\end{abstract}

\footnotetext{
* Correspondence: harshima@path.cmb.ac.lk; harshima@hotmail.com 'Department of Pathology, Faculty of Medicine, University of Colombo, Colombo, Sri Lanka

Full list of author information is available at the end of the article
}

(c) The Author(s). 2020 Open Access This article is licensed under a Creative Commons Attribution 4.0 International License, which permits use, sharing, adaptation, distribution and reproduction in any medium or format, as long as you give appropriate credit to the original author(s) and the source, provide a link to the Creative Commons licence, and indicate if changes were made. The images or other third party material in this article are included in the article's Creative Commons licence, unless indicated otherwise in a credit line to the material. If material is not included in the article's Creative Commons licence and your intended use is not permitted by statutory regulation or exceeds the permitted use, you will need to obtain permission directly from the copyright holder. To view a copy of this licence, visit http://creativecommons.org/licenses/by/4.0/. The Creative Commons Public Domain Dedication waiver (http://creativecommons.org/publicdomain/zero/1.0/) applies to the data made available in this article, unless otherwise stated in a credit line to the data. 
(Continued from previous page)

Conclusions: AR prevalence obtained was low. AR positivity was associated with positivity for ER and PR. On multivariate analysis, apart from TNM stage only ER/AR status were predictive of OS and DFS, with concordant expression of ER/AR demonstrating a better, early survival.

Keywords: Breast carcinoma, Androgen receptors, Prevalence, Prognosis, Clinicopathological features, Sri Lanka

\section{Background}

Breast carcinoma ( $\mathrm{BCa})$ is the commonest malignancy among women in Sri Lanka and worldwide. In 2010, $27 \%$ of women diagnosed with cancer in Sri Lanka had $\mathrm{BCa}$ with a lifetime risk of $2.5 \%$ in the population [1].

$\mathrm{BCa}$ can be categorized into several molecular subtypes based on the surrogate immunohistochemical marker expression. Oestrogen receptors (ER), progesterone receptors (PR), HER2, Ki67 and basal markers (CK5/6, CK14, CK17, 34ßE12 and EGFR) are analyzed by immunohistochemistry (IHC). Based on these results the tumours are categorized into Luminal A, Luminal B, HER2 enriched, triple negative and basal like subtypes $[2,3]$. The IHC defined molecular subtype of a tumour has a significant impact on treatment decisions. It is predictive of response to treatment and important in the assessment of prognosis [4].

Expression of androgen receptors (AR) in $\mathrm{BCa}$ has generated considerable interest in the recent past as a prognostic biomarker. The human androgen receptor $A R$ gene is located in the $\mathrm{X}$ chromosome at position $\mathrm{Xq11-12}$. It is known to produce its effects through 3 major pathways which contribute to AR function in $\mathrm{BCa}$ : genomic signaling, non-genomic signaling and signaling via cross talk with growth factors and cytokines [5]. Different signaling pathways are seen in the different molecular subtypes of BCa. In ER-positive BCa, AR signaling often antagonizes the growth stimulatory effect of ER signaling; in luminal AR subtype of TNBC identified by molecular assays, AR seems to drive tumor progression; in HER2-positive BCa, in the absence of ER expression, AR signaling has a proliferative role [6]. This explains why the prognostic impact of AR has been shown to be dependent on the molecular subtype of tumour [7-10]. It is also the rationale behind the use of androgen agonists in some AR-positive/ER-positive tumors $(\mathrm{AR}+/ \mathrm{ER}+)$ and $\mathrm{AR}$ antagonists in triple-negative/AR-positive tumors (TNBC/ $\mathrm{AR}+$ ) and a combination of $\mathrm{AR}$ antagonists and antiHER2 agents or other signaling pathway inhibitors in HER2-positive/AR- positive (HER2+/AR+) tumors [6, 11].

Systematic reviews and meta-analysis have shown AR positivity to be associated with favorable clinical outcomes $[12,13]$. However these studies did not provide evidence on prognostic relevance of AR in different breast cancer subtypes. A correct understanding of the prognostic value of $A R$ in each breast cancer subtype would be of value in refining the prognostic and predictive outcomes in each specific subgroup of early breast cancer patients. It is also crucial for the development of $\mathrm{AR}$ agonist and antagonist therapies.

Data regarding the prevalence and the impact of AR expression in $\mathrm{BCa}$ and survival are mostly from the west and none from Sri Lanka. Only a few studies have been done in Asia; in Iran, India, Thailand and China [1417].

We aimed to determine the prevalence of androgen receptor expression by immunohistochemical analysis among a cohort of Sri Lankan women with early breast carcinoma, and to evaluate its association with clinical and pathological features including immunohistochemical molecular subtype and early survival.

\section{Methods \\ Sample selection}

Ethical approval for the study was obtained from the Ethical Review Committee of the Faculty of Medicine, University of Colombo (EC-17-088). The study population comprised all women undergoing surgery for invasive breast carcinoma at the National Hospital of Sri Lanka from June 2012 to December 2014. Inclusion criteria were women undergoing mastectomy or wide-local excision for an invasive breast carcinoma of early stage. Early stage breast carcinoma was defined as cancer confined to the breast with or without regional lymph node involvement, and absent distant metastasis [18]. Patients with mixed in situ and invasive carcinoma were included. Poor tumour fixation and neoadjuvant chemotherapy have been shown to alter histopathological and ER/PR and HER2 receptor status of $\mathrm{BCa}$ [19]. Therefore women with $\mathrm{BCa}$ undergoing surgery following neoadjuvant therapy and tumours with evidence of poor fixation (suboptimal tumour preservation involving $\geq 80 \%$ of the tumour) were excluded. Other exclusion criteria were lack of follow-up data, nonavailability of tissue blocks and cases with microcarcinoma having inadequate invasive carcinoma for analysis of all histopathological parameters.

\section{Sample size}

The study population comprised 301 patients. One hundred and forty one cases were selected from 179 cases fulfilling the inclusion and exclusion criteria. 


\section{Evaluation of clinicopathological parameters}

The clinical parameters evaluated included ethnicity, age, body mass index, parity, history of breast feeding, menopausal status, family history of $\mathrm{BCa}$ and use of oral contraceptives and hormone therapy. The clinical data was collected by the investigators through patient interviews. The following information was retrieved from the pathology reports: type of surgery, tumour size, margin involvement and lymph node status. Slides of cases that had been reported as having a positive margin were reviewed to confirm the presence of margin involvement. Only cases showing the presence of tumour on the ink were classified as having a positive margin. The haematoxylin and eosin stained slides of the tumour were evaluated by the investigators for the following parameters: histological type, histological grade, necrosis, ductal carcinoma in situ (DCIS), lymphovascular invasion, tumour margins, degree of lymphoid infiltrate at the tumour-host interface and within the tumour, degree of desmoplasia/hyalinization at the tumour-host interface and within the tumour, vascular density at the tumour-host interface, cell margins and calcification. Histological subtyping was done according to the 4th World Health Organization Classification of Tumours of the Breast [20]. The Elston-Ellis modification of ScarffBloom-Richardson grading system [21] was used to determine the histological grade. Tumour margins were assessed qualitatively and categorized as pushing or infiltrative. A pushing margin was defined as a broad well defined margin with tumour cells arranged in clusters or islands at the tumour-host interface. The tumour and tumour-host interface were screened on X10 magnification to assess the degree of lymphoid infiltrate and desmoplasia. These were assessed semi-quantitatively. They were categorized as absent to mild (lymphoid infiltrate/ desmoplasia $\leq 1 / 3$ of the area assessed) and moderate to severe (lymphoid infiltrate/desmoplasia involving $>1 / 3$ of the area assessed. The vascular density at the tumour host interface was assessed in the area of highest vascular density and categorized into two categories $(<5$ blood vessels/medium power field and $\geq 5$ blood vessels/ medium power field. A medium power field was a field with a field diameter of $0.2 \mathrm{~mm}$ on $\times 10$ magnification.

\section{Immunohistochemical analysis}

Immunohistochemical staining for ER, PR, HER2 and AR were performed by investigators on representative paraffin embedded tissue in all selected cases. CK5/6, EGFR, 34ßE12 and CK14 were evaluated in the cases found to be triple negative (Negative for ER, PR and HER2). Relevant negative and positive control slides were included with each batch of slides stained with immunohistochemical markers.
The antibodies, dilution and the method used and interpretation of IHC stained sections are shown in Table 1. All cases were evaluated by the investigators. The cut-off point used for positivity versus negativity for ER, PR or AR status was greater than or equal to $1 \%$ of tumour cells $[19,22]$. The ASCO - CAP guideline of 2013 was used for the interpretation of HER2 [23]. Tumours that were equivocal for HER2 (HER2-2+) by IHC were further evaluated by by fluorescent in situ hybridization (FISH) to determine the HER2 status.

The tumours were broadly categorized into luminal, HER2 and triple negative breast carcinoma (TNBC) groups based on ER, PR and HER2 status. A proportion of the luminal breast carcinomas could have been further subclassified as luminal B, based on positivity for HER2 [3]. However, further classification of the luminal subgroup into luminal A and B was not attempted as the proliferative index by Ki67 was not evaluated in all cases. The triple negative tumours were subdivided into two groups based on the expression of basal markers, i.e. non-basal triple negative (basal markers negative) and basal triple negative (basal markers positive).

\section{Collection of survival data}

All patients had been treated and managed according to standard protocols [25] with 119 women undergoing mastectomy and 22 undergoing wide local excision respectively. Subsequent adjuvant therapy options included combinations of hormonal therapy with anti oestrogenic agents (in ER and/or PR positive tumours), antiHER2 therapy (in HER2 positive tumours), chemotherapy and radiotherapy. Androgen receptor agonists and antagonists were not used in the treatment. Treatment received, early overall survival (OS) and disease-free survival (DFS) at short term was determined from patient interviews and review of clinic records.

\section{Statistical analysis}

Proportions and 95\% confidence intervals were calculated to estimate prevalence. The relationship between clinicopathological parameters, IHC molecular subtype and the AR expression was analyzed using Student $\mathrm{T}$ test and chi-square tests. A $p$ value of $<0.05$ was taken as significant. Univariate Cox regression analysis was used to analyze the prognostic impact (OS and DFS) of AR expression on the entire sample as a whole and also when stratified according to histological grade, ER status and menopausal status. Multivariate Cox regression analysis was performed to analyse factors affecting OS and DFS. Statistical Package for the Social Sciences SPSS (IBM Corp. Released 2016. IBM SPSS Statistics for Windows, Version 20.0. Armonk, NY: IBM Corp.) was used for data analysis. 


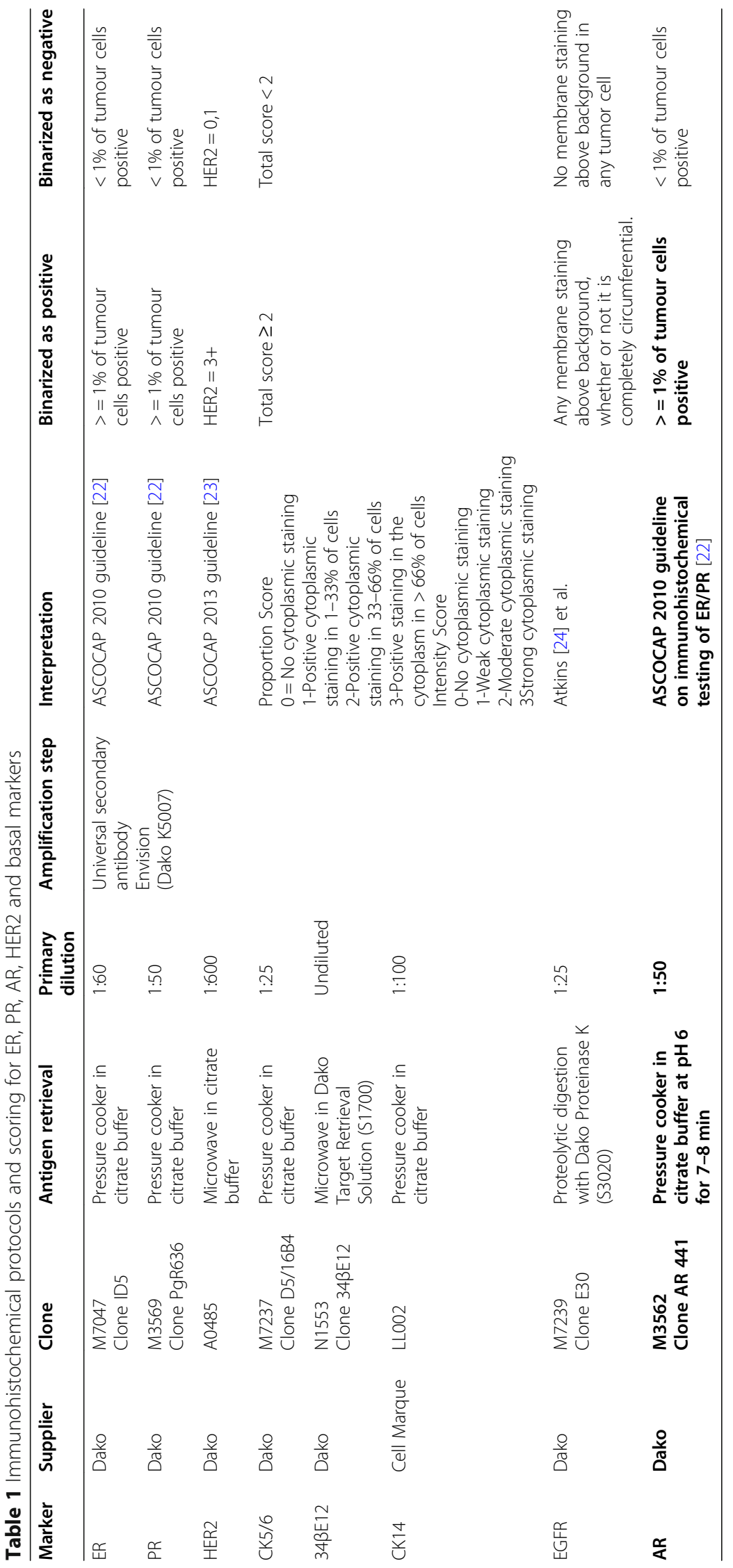




\section{Results}

\section{Characteristics of the study sample}

The characteristics of the study sample are summarized in Table 2. The mean age of the cohort was 55.46 years (95\% CI 53.6-57.3 years) ranging from 29 to 77 years. The majority were postmenopausal (97/148-68.8\%) and overweight (Mean BMI $26.69 \mathrm{~kg} / \mathrm{m}^{2}-95 \%$ CI $25.7-27.7$ $\mathrm{kg} / \mathrm{m}^{2}$ ). Eleven $(7.8 \%)$ had a family history of breast carcinoma.

\section{Prevalence of AR expression}

Positive AR expression (Fig. 1) was seen in 40.8\% (95\% CI $33.10-49.07 \%$ ) of the study cohort.

\section{Association of AR expression with clinical and pathological features}

None of the clinical data studied showed a significant association with either AR-positive or negative status $(p>$ 0.05) (Table 3). Of the pathological features studied DCIS $(p=0.003)$ and positivity for ER $(p=0.001)$ and PR $(p=0.001)$ were associated with AR positivity. ARnegativity was significantly associated with necrosis > $50 \%(p=0.031)$ and a moderate to extensive lymphocytic infiltrate at the tumour margin $(p=0.025)$ (Table 4).

Association of AR expression with IHC molecular subtypes AR was expressed across all IHC molecular subtypes, with $50.6 \%$ of luminal, $29.4 \%$ of HER2 and $21.6 \%$ of TNBC subtypes showing AR-positivity. The association of AR status and the IHC molecular subtype is shown in Table 5. AR status showed a statistically significant association with the tumour IHC molecular subtype ( $p=$ $0.016)$ and AR-positivity was associated with the luminal subtype. Basal triple negative breast carcinomas showed an association with AR negativity.

\section{Survival data of study sample}

The mean duration of follow up was 46.70 (95\% CI 46.495-46.905) months (3.89 years). One hundred and seven patients were alive and free of disease. There were 34 cases of early relapse. Twenty five patients died during this period. Of the nine that were living with disease, six had developed metastases and three had local recurrences.

Positive margin involvement was seen in ten cases (7.1\%), of which eight were mastectomies and two were wide local excisions in which no subsequent mastectomy was performed. Three of the patients who died, had positive margin involvement at the time of primary surgery. All three had undergone mastectomy. The remaining seven patients were disease free at follow up.

\section{AR status and survival}

Androgen receptor status showed no significant association with OS $(p=0.351)$ and DFS $(p=0.840)$. Post-hoc calculations of the power of the study showed that the power of the study to detect a difference in DFS and OS between the two groups (AR+ vs AR-) with an alpha value of 0.05 was 4.6 and $11.2 \%$ respectively.

\section{$A R$ status and survival in sub groups}

Menopausal status and survival The tumours were evaluated in sub-groups based on the menopausal and ER/AR status. Postmenopausal women with ER-positive, AR-positive $(E R+/ A R+)$ tumours showed significantly better OS than postmenopausal women with ERpositive, AR-negative (ER+/AR-) tumours $(p=0.030)$ (Fig. 2). DFS did not differ among the different ER/AR expression subgroups of postmenopausal women. There was no statistically significant difference in OS or DFS among the different ER/AR expression subgroups among premenopausal women.

Histological grade and survival Grade 3/AR-positive tumours had the worst OS and DFS. The OS $(p=0.035)$ and DFS $(p=0.022)$ of this subgroup was significantly different from the grade $1 / 2 / \mathrm{AR}$-positive tumours. Additionally among grade $1 / 2$ tumours, AR-positive tumours showed a significantly better OS $(p=0.042)$ than ARnegative tumours (Fig. 3).

ER/AR status and survival On univariate Cox regression analysis ER+/AR+ tumours showed significantly better OS than ER+/AR- tumours $(p=0.047)$ and ERnegative, AR-negative (ER-/AR-) tumours showed significantly better DFS than ER-negative, AR-positive (ER $-/ \mathrm{AR}+)$ tumours $(p=0.036)$ (Fig. 4).

Molecular subtype and survival The AR status of the tumour had no impact on either overall $(p=0.293)$ or disease-free survival $(p=0.826)$ when the tumours were categorized by molecular subgroup.

Multivariate analysis On multivariate Cox regression the ER/AR status and TNM stage were the only factors predictive of OS and DFS. ER+/AR- tumours had a significantly worse OS than ER+/AR+ tumours $(p=0.015)$ and ER-/AR+ tumours had significantly worse DFS than ER-/AR-tumours $(p=0.014)$ (Tables 6 and 7).

\section{Discussion}

The prevalence of AR expression has shown a wide variation, ranging from 37.04 to $77 \%$ in different studies [14-16, 26-28]. The prevalence of AR positivity was $40.8 \%$ among this cohort of Sri Lankan women with 
Table 2 Clinical and pathological characteristics of the study sample

\begin{tabular}{|c|c|c|c|c|c|}
\hline Clinico-pathological feature & & $\begin{array}{l}\text { Mean (SD) } \\
\text { or Number } \\
\text { (Percentage) }\end{array}$ & Clinico-pathological feature & & $\begin{array}{l}\text { Mean (SD) } \\
\text { or Number } \\
\text { (Percentage) }\end{array}$ \\
\hline Age & Mean age (years) & $55.46(11.28)$ & PR & Positive & $75(53.6 \%)$ \\
\hline Body Mass Index & Mean BMI $\left(\mathrm{kg} / \mathrm{m}^{2}\right)$ & $26.69(6.24)$ & & Negative & $65(46.4 \%)$ \\
\hline \multirow[t]{3}{*}{ Ethnicity } & Sinhalese & $115(81.6 \%)$ & HER 2 & Positive & $20(14.9 \%)$ \\
\hline & Tamil & $13(9.2 \%)$ & & Negative & $121(85.1 \%)$ \\
\hline & Moor & $13(9.2 \%)$ & Molecular subtypes & Luminal & $87(61.7 \%)$ \\
\hline \multirow[t]{2}{*}{ Menopausal status } & Premenopausal & $44(31.2 \%)$ & & HER 2 & $17(12.1 \%)$ \\
\hline & Post-menopausal & $97(68.8 \%)$ & & Triple negative & $37(26.2 \%)$ \\
\hline \multirow[t]{3}{*}{ Parity } & Nulliparous & $14(9.9 \%)$ & Type of surgery & Wide - local excision & $22(15.6 \%)$ \\
\hline & Parous & $122(86.5 \%)$ & & Mastectomy & $119(84.4 \%)$ \\
\hline & Not available & $5(3.5 \%)$ & Type of adjuvant therapy & Hormonal treatment & $50(59.5 \%)$ \\
\hline \multirow{3}{*}{$\begin{array}{l}\text { History of oral } \\
\text { contraceptive use }\end{array}$} & Present & $27(19.1 \%)$ & $\begin{array}{l}\text { (speciflc treatment detalls } \\
\text { were available in } 84 \text { patients) }\end{array}$ & Chemotherapy & $32(38.1 \%)$ \\
\hline & Absent & 109 (77.3\%) & & Trastuzumab & $10(11.9 \%)$ \\
\hline & Not available & $5(3.5 \%)$ & & Radiotherapy & $9(10.7 \%)$ \\
\hline
\end{tabular}

History of use of hormone replacement therapy

History of breast feeding

Family history of breast cancer

Absent

TNM stage*

Nodal stage* (Lymph nodes were assessed in 128 patients)

$\begin{array}{ll} & \mathrm{N} 2 \\ & \mathrm{~N} 3 \\ \text { Histology type } & \text { Ductal } \\ & \text { Lobular } \\ & \text { Mucinous } \\ & \text { Micropapillary } \\ & \text { Metaplastic } \\ & \text { Adenoid cystic } \\ & \text { Carcinoma with } \\ \text { neuroendocrine } \\ \text { features }\end{array}$

Histology grade

Grade 1

$31(22.0 \%)$

Grade 2

$51(36.2 \%)$

Grade 3

$59(41.8 \%)$

Receptor status

ER

Positive

$68(49.3 \%)$

Negative
Table 2 Clinical and pathological characteristics of the study sample (Continued)

early breast cancer. The expression of AR is low in comparison to most studies. However studies conducted in Poland (43\%) [26], Egypt (37.04\%) [27] and India (56\%) [15] have also reported low levels of AR expression. This wide variation in AR expression could be due to differences in tumour biology. Additionally studies have used different methods to determine AR expression (immunohistochemistry and gene expression profiling) and different cut offs (e.g. staining of $\geq 1 \%$ of cells or $\geq$ $10 \%$ of cells) to identify AR positive tumours by immunohistochemistry $[10,12,29]$ Other factors that may have contributed to the low level of AR expression in this study include the exclusion of women who had received neo-adjuvant chemotherapy and false negativity due to the instability of the AR protein in stored tissue blocks.

Although some studies have shown that AR immune reactivity was related significantly to patient's age and post-menopausal state [27], none of the clinical features that we studied showed an association with AR status. Pathological features associated with AR negativity included tumour necrosis involving $>50 \%$ of the tumor and a prominent lymphoid infiltrate at the tumour margin. These are features seen in basal like breast carcinoma [30] which was also shown to be associated with an $\mathrm{AR}$ - negative status.

Expression of AR receptor has been reported to vary between different IHC molecular subtypes. Studies performed in western settings such as in Germany, United States of America and Spain have reported an ARpositivity of $84-95 \%$ in ER-positive, $50-63 \%$ in ERnegative and $10-53 \%$ in TNBC [31]. The overall expression of AR was less across all tumour subgroups in the 

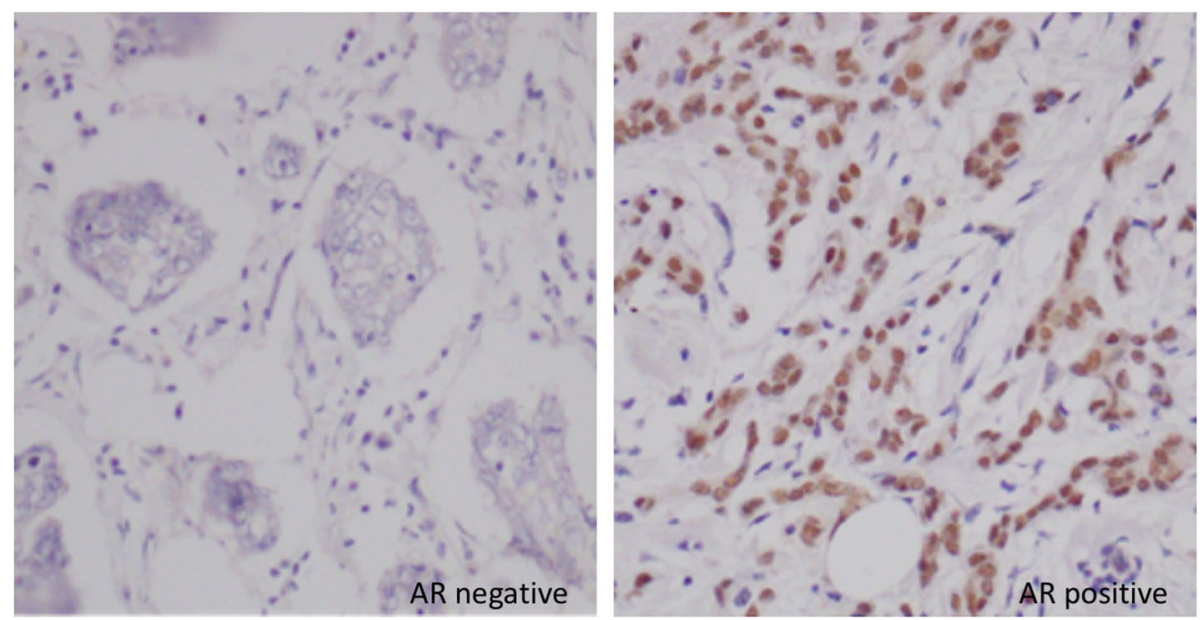

Fig. 1 Immunohistochemical staining for AR in breast carcinoma

Table 3 Association of clinical features and AR status

\begin{tabular}{|c|c|c|c|c|}
\hline \multirow[t]{2}{*}{ Clinical feature } & & \multicolumn{2}{|l|}{ AR Status } & \multirow{2}{*}{$\begin{array}{l}p \text {-value } \\
\text { (Student } \\
\mathrm{t}-\text { test, } \\
\text { chi square) }\end{array}$} \\
\hline & & Positive & Negative & \\
\hline Age (years) & Mean age (years) & 57.19 & 54.20 & $0.125^{\mathrm{a}}$ \\
\hline Body Mass Index & Mean BMI $\left(\mathrm{kg} / \mathrm{m}^{2}\right)$ & 26.82 & 26.61 & $0.863^{\mathrm{a}}$ \\
\hline \multirow[t]{3}{*}{ Ethnicity } & Sinhalese & $44(77.2 \%)$ & $71(84.5 \%)$ & $0.503^{b}$ \\
\hline & Tamil & $7(12.3 \%)$ & $6(7.1 \%)$ & \\
\hline & Moor & $6(10.5 \%)$ & $7(8.3 \%)$ & \\
\hline \multirow[t]{2}{*}{ Menopausal status } & Premenopausal & $13(22.8 \%)$ & $31(36.9 \%)$ & $0.076^{\mathrm{b}}$ \\
\hline & Post-menopausal & $44(77.2 \%)$ & $53(63.1 \%)$ & \\
\hline \multirow[t]{3}{*}{ Parity } & Nulliparous & $8(14.0 \%)$ & $6(7.1 \%)$ & $0.405^{b}$ \\
\hline & Parous & $47(82.5 \%)$ & 75 (89.3\%) & \\
\hline & Not available & $2(3.5 \%)$ & $3(3.6 \%)$ & \\
\hline \multirow[t]{3}{*}{ History of oral contraceptive use } & Present & $9(15.8 \%)$ & $18(21.4 \%)$ & $0.498^{b}$ \\
\hline & Absent & $45(78.9 \%)$ & $64(76.2 \%)$ & \\
\hline & Not available & $3(5.3 \%)$ & $2(2.4 \%)$ & \\
\hline \multirow[t]{3}{*}{ History of use of hormone replacement therapy } & Present & $2(3.5 \%)$ & $0(0 \%)$ & $0.195^{b}$ \\
\hline & Absent & $52(91.2 \%)$ & $81(96.4 \%)$ & \\
\hline & Not available & $3(5.3 \%)$ & $3(3.6 \%)$ & \\
\hline \multirow[t]{3}{*}{ History of breast feeding } & Present & $46(80.7 \%)$ & $74(88.1 \%)$ & $0.390^{\mathrm{b}}$ \\
\hline & Absent & $9(15.8 \%)$ & $7(8.3 \%)$ & \\
\hline & Not available & $2(3.5 \%)$ & $3(3.6 \%)$ & \\
\hline \multirow[t]{2}{*}{ Family history of breast cancer } & Present & $3(5.3 \%)$ & $8(9.5 \%)$ & $0.355^{\mathrm{b}}$ \\
\hline & Absent & $54(94.7 \%)$ & $76(90.5 \%)$ & \\
\hline
\end{tabular}

${ }^{\text {a }}$ Statistical test - Student T test. ${ }^{\mathrm{b}}$ Statistical test - Chi square test

Percentages have been calculated to represent the prevalence of each clinical feature within each category of AR status 
Table 4 Association of pathological parameters and AR expression

\begin{tabular}{|c|c|c|c|c|}
\hline \multirow[t]{2}{*}{ Pathological Parameter } & & \multicolumn{2}{|c|}{ AR expression } & \multirow{2}{*}{$\begin{array}{l}p \text {-value } \\
\text { (Chi - square) }\end{array}$} \\
\hline & & Positive & Negative & \\
\hline \multirow[t]{7}{*}{ Histological type } & Ductal & $49^{a}(86.0 \%)$ & $76^{\mathrm{a}}(90.5 \%)$ & 0.657 \\
\hline & Lobular & $3^{\mathrm{a}}(5.3 \%)$ & $3^{\mathrm{a}}(3.6 \%)$ & \\
\hline & Mucinous & $2^{\mathrm{a}}(3.5 \%)$ & $1^{\mathrm{a}}(1.2 \%)$ & \\
\hline & Micropapillary & $0^{\mathrm{a}}(0 \%)$ & $1^{\mathrm{a}}(1.2 \%)$ & \\
\hline & Metaplastic & $2^{\mathrm{a}}(3.5 \%)$ & $2^{\mathrm{a}}(2.4 \%)$ & \\
\hline & Adenoid cystic carcinoma & $0^{\mathrm{a}}(0 \%)$ & $1^{\mathrm{a}}(1.2 \%)$ & \\
\hline & Carcinoma with neuroendocrine features & $1^{\mathrm{a}}(1.8 \%)$ & $0^{\mathrm{a}}(0 \%)$ & \\
\hline \multirow[t]{3}{*}{ T stage } & $\mathrm{T} 1$ & $11^{\mathrm{a}}(19.3 \%)$ & $13^{\mathrm{a}}(15.5 \%)$ & 0.593 \\
\hline & $\mathrm{T} 2$ & $41^{\mathrm{a}}(71.9 \%)$ & $65^{\mathrm{a}}(77.4 \%)$ & \\
\hline & T3 & $5^{\mathrm{a}}(8.8 \%)$ & $6^{\mathrm{a}}(7.1 \%)$ & \\
\hline \multirow[t]{4}{*}{ N stage } & No & $27^{\mathrm{a}}(55.1 \%)$ & $45^{\mathrm{a}}(57.0 \%)$ & 0.452 \\
\hline & N1 & $11^{\mathrm{a}}(22.4 \%)$ & $15^{\mathrm{a}}(19.0 \%)$ & \\
\hline & N2 & $7^{\mathrm{a}}(14.3 \%)$ & $7^{\mathrm{a}}(8.9 \%)$ & \\
\hline & N3 & $4^{\mathrm{a}}(8.2 \%)$ & $12^{\mathrm{a}}(15.2 \%)$ & \\
\hline \multirow[t]{3}{*}{ TNM stage } & Stage 1 & $8^{\mathrm{a}}(14.0 \%)$ & $9^{a}(10.7 \%)$ & 0.797 \\
\hline & Stage 11 & $36^{\mathrm{a}}(63.2 \%)$ & $57^{\mathrm{a}}(67.9 \%)$ & \\
\hline & Stage 111 & $13^{\mathrm{a}}(22.8 \%)$ & $18^{\mathrm{a}}(21.4 \%)$ & \\
\hline \multirow[t]{3}{*}{ Histological Grade } & Grade 1 & $15^{\mathrm{a}}(26.3 \%)$ & $16^{\mathrm{a}}(19.0 \%)$ & 0.497 \\
\hline & Grade 2 & $21^{\mathrm{a}}(36.8 \%)$ & $30^{\mathrm{a}}(35.7 \%)$ & \\
\hline & Grade 3 & $21^{\mathrm{a}}(36.8 \%)$ & $38^{\mathrm{a}}(45.2 \%)$ & \\
\hline \multirow[t]{2}{*}{ Ductal carcinoma in situ } & Absent & $21^{\mathrm{a}}(36.8 \%)$ & $52^{b}(61.9 \%)$ & $0.003^{*}$ \\
\hline & Present & $36^{\mathrm{a}}(63.2 \%)$ & $32^{\mathrm{b}}(38.1 \%)$ & \\
\hline \multirow[t]{3}{*}{ Necrosis } & Absent & $38^{\mathrm{a}}(66.7 \%)$ & $48^{\mathrm{a}}(57.1 \%)$ & $0.031^{*}$ \\
\hline & Focal & $15^{\mathrm{a}}(26.3 \%)$ & $16^{\mathrm{a}}(19.0 \%)$ & \\
\hline & Moderate-extensive & $4^{a}(7.0 \%)$ & $20^{\mathrm{b}}(\mathbf{2 3 . 8 \%})$ & \\
\hline \multirow[t]{2}{*}{ Tumour margin } & Pushing & $43^{\mathrm{a}}(75.4 \%)$ & $64^{\mathrm{a}}(76.2 \%)$ & 0.918 \\
\hline & Infiltrative & $14^{\mathrm{a}}(24.6 \%)$ & $20^{\mathrm{a}}(23.8 \%)$ & \\
\hline \multirow[t]{2}{*}{ Lympho vascular invasion } & Absent & $48^{\mathrm{a}}(84.2 \%)$ & $76^{\mathrm{a}}(90.5 \%)$ & 0.262 \\
\hline & Present & $9^{a}(15.8 \%)$ & $8^{\mathrm{a}}(9.5 \%)$ & \\
\hline \multirow[t]{2}{*}{ Central desmoplasia/Hyalinization } & Absent to mild & $24^{\mathrm{a}}(42.1 \%)$ & $40^{\mathrm{a}}(47.6 \%)$ & 0.519 \\
\hline & Moderate-extensive & $33^{\mathrm{a}}(57.9 \%)$ & $44^{\mathrm{a}}(52.4 \%)$ & \\
\hline \multirow[t]{2}{*}{ Desmoplasia/hyalinisation at edge } & Absent to mild & $43^{\mathrm{a}}(75.4 \%)$ & $68^{\mathrm{a}}(81.0 \%)$ & 0.432 \\
\hline & Moderate to extensive & $14^{\mathrm{a}}(24.6 \%)$ & $16^{\mathrm{a}}(19.0 \%)$ & \\
\hline \multirow[t]{2}{*}{ Lymphoid infiltrate in centre } & Absent to mild & $49^{\mathrm{a}}(86.0 \%)$ & $66^{\mathrm{a}}(78.6 \%)$ & 0.267 \\
\hline & Moderate to extensive & $8^{\mathrm{a}}(14.0 \%)$ & $18^{\mathrm{a}}(21.4 \%)$ & \\
\hline \multirow[t]{2}{*}{ Lymphoid infiltrate at edge } & Absent to mild & $46^{\mathrm{a}}(80.7 \%)$ & $53^{b}(63.1 \%)$ & $0.025^{*}$ \\
\hline & Moderate to extensive & $11^{\mathrm{a}}(19.3 \%)$ & $31^{\mathrm{b}}(36.9 \%)$ & \\
\hline \multirow[t]{2}{*}{ Vascular density at edge } & $<5$ vessels $/ \mathrm{mpf}$ & $16^{\mathrm{a}}(28.1 \%)$ & $21^{\mathrm{a}}(25.0 \%)$ & 0.684 \\
\hline & $\geq 5$ vessels $/ \mathrm{mpf}$ & $41^{\mathrm{a}}(71.9 \%)$ & $63^{\mathrm{a}}(75.0 \%)$ & \\
\hline \multirow[t]{2}{*}{ Calcification } & Absent & $52^{\mathrm{a}}(91.2 \%)$ & $79^{a}(94.0 \%)$ & 0.522 \\
\hline & Present & $5^{\mathrm{a}}(8.8 \%)$ & $5^{\mathrm{a}}(6.0 \%)$ & \\
\hline \multirow[t]{2}{*}{ Cell margins } & Distinct & $26^{\mathrm{a}}(45.6 \%)$ & $42^{\mathrm{a}}(50.0 \%)$ & 0.609 \\
\hline & Indistinct & $31^{\mathrm{a}}(54.4 \%)$ & $42^{\mathrm{a}}(50.0 \%)$ & \\
\hline
\end{tabular}


Table 4 Association of pathological parameters and AR expression (Continued)

\begin{tabular}{|c|c|c|c|c|}
\hline \multicolumn{2}{|c|}{ Pathological Parameter } & \multicolumn{2}{|c|}{ AR expression } & \multirow{2}{*}{$\begin{array}{l}p \text {-value } \\
\text { (Chi - square) }\end{array}$} \\
\hline & & Positive & Negative & \\
\hline \multirow[t]{2}{*}{ ER status } & Positive & $36^{\mathrm{a}}(66.7 \%)$ & $32^{\mathrm{b}}(38.1 \%)$ & $0.001 *$ \\
\hline & Negative & $18^{\mathrm{a}}(33.3 \%)$ & $52^{\mathrm{b}}(61.9 \%)$ & \\
\hline \multirow[t]{2}{*}{ PR status } & Positive & $40^{\mathrm{a}}(70.2 \%)$ & $35^{\mathrm{b}}(42.2 \%)$ & $0.001 *$ \\
\hline & Negative & $17^{\mathrm{a}}(29.8 \%)$ & $48^{\mathrm{b}}(57.8 \%)$ & \\
\hline \multirow[t]{2}{*}{ HER2 status } & Positive & 7a $(12.3 \%)$ & 13a $(15.5 \%$ & 0.594 \\
\hline & Negative & 50a (87.7\%) & $71 a(84.5 \%)$ & \\
\hline \multirow[t]{3}{*}{ Treatment } & Hormonal treatment & $27^{\mathrm{a}}(75.0 \%)$ & $23^{b}(47.9 \%)$ & $0.012^{*}$ \\
\hline & Chemotherapy & $7^{\mathrm{a}}(19.4 \%)$ & $25^{\mathrm{b}}(55.6 \%)$ & $0.001 *$ \\
\hline & Anti HER2 therapy & $2 \mathrm{a}(5.7 \%)$ & 8a 17.4\%) & 0.114 \\
\hline
\end{tabular}

*Statistically significant ${ }^{a, b}$ Each superscript letter denotes a subtype whose column proportions do not differ significantly from each other at the 0.05 level $\mathrm{hpf}-$ High power field ( $\times 40$ objective, field diameter $0.05 \mathrm{~mm}$ ) $\mathrm{mpf}$ - Medium power field ( $\times 10$ objective, field diameter $0.2 \mathrm{~mm}$ )

Percentages have been calculated to represent the prevalence of each clinical feature within each category of AR status

study population. However the same trend was demonstrated in the study and AR-positivity was present in $50.6 \%$ of luminal, $29.4 \%$ of HER2 and $21.6 \%$ of TNBC subtypes.

All patients were treated with surgery followed by adjuvant therapy, which included hormonal therapy, chemotherapy and radiation therapy, determined by standard treatment protocols. As expected given the association of AR positivity with ER positivity, AR positivity was associated with hormonal treatment and AR negativity with treatment with chemotherapy.

AR expression was not significantly related to the overall and disease-free survival in this study (mean duration of follow up - 46.70 months). However, many studies including a metanalysis of 22 studies involving 10,004 women [12] found that AR positivity was associated with favorable OS and DFS. The small sample size of this study may be a contributing factor for this difference.

The prognostic effect of AR expression may vary according to the age, menopausal status, and hormonal status of the tumour. Although the mean age was 55.46 years and most participants were in the post- menopausal age group, their age ranged widely from 29 to 77 years. The cases included both ER positive and ER negative cancers. This clinical heterogeneity needs to be taken into consideration, when interpreting the results of the group as a whole. Subsequent subgroup analysis was done according to menopausal status, tumour grade and ER status.

Postmenopausal women with ER+ tumours comprised a subgroup with limited clinical heterogeneity. We found that AR-positivity was associated with a better OS among postmenopausal women with ER-positive tumors. This same association was not seen among premenopausal women with ER-positive tumours. Androgen is thought to act as an anti-oestrogen in premenopausal women, but as an oestrogen agonist in postmenopausal women. Therefore it is possible that the prognostic implications of AR status may be dependent on the menopausal status. However the smaller numbers of women in the premenopausal group (44 premenopausal women vs 98 postmenopausal women) is a limitation that must be considered when interpreting the findings. $\mathrm{Hu}$ et al. who studied postmenopausal women also found AR expression to be associated with a more favorable

Table 5 IHC Molecular subtype and AR expression

\begin{tabular}{|c|c|c|c|}
\hline \multirow[t]{2}{*}{ IHC molecular subtype } & \multicolumn{2}{|c|}{ AR expression } & \multirow{2}{*}{$\frac{p \text {-value }}{p=0.016}$} \\
\hline & Positive & Negative & \\
\hline Luminal & $\begin{array}{l}44^{\mathrm{a}} \\
(77.2 \%)\end{array}$ & $\begin{array}{l}43^{b} \\
(51.2 \%)\end{array}$ & \\
\hline HER2 & $\begin{array}{l}5^{\mathrm{a}} \\
(8.8 \%)\end{array}$ & $\begin{array}{l}12^{\mathrm{a}} \\
(14.3 \%)\end{array}$ & \\
\hline Non-basal TNBC & $\begin{array}{l}5^{\mathrm{a}} \\
(8.8 \%)\end{array}$ & $\begin{array}{l}14^{\mathrm{a}} \\
(16.7 \%)\end{array}$ & \\
\hline Basal TNBC & $\begin{array}{l}3^{\mathrm{a}} \\
(5.3 \%)\end{array}$ & $\begin{array}{l}15^{\mathrm{b}} \\
(17.9 \%)\end{array}$ & \\
\hline
\end{tabular}

$\overline{\mathrm{a}, \mathrm{b}}$ Each superscript letter denotes a subtype whose column proportions do not differ significantly from each other at the 0.05 level 


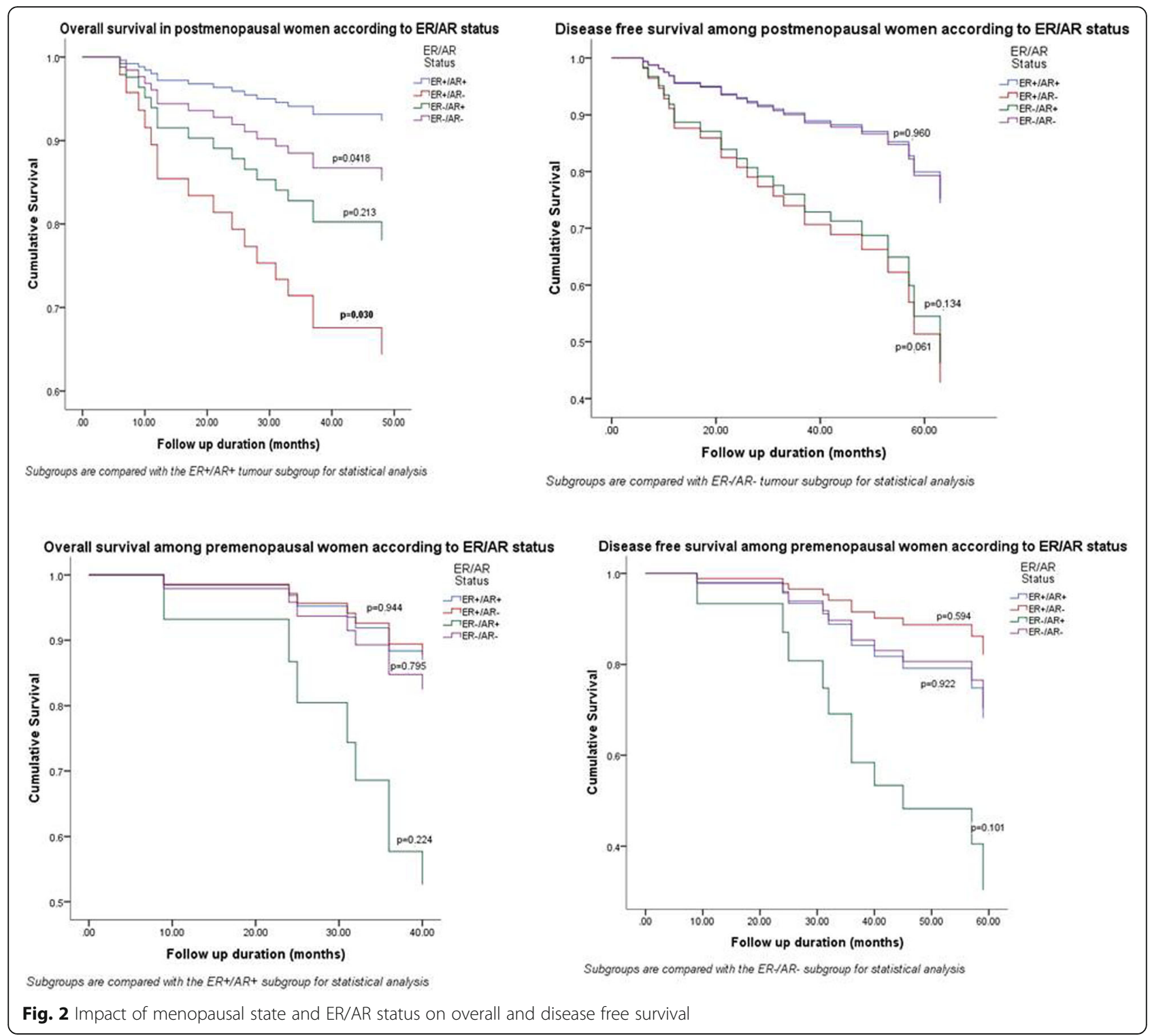

prognosis in ER-positive tumors [10]. However the more recent breast international group trial 1-98 found that AR expression was not associated with prognosis in postmenopausal women with ER positive early breast cancer [32].

Among grade $1 / 2$ tumours, AR positive tumours showed a better prognosis than AR negative tumours. However this may be due to the fact that low grade tumours were more likely to be ER positive. $\mathrm{ER}+/ \mathrm{AR}+$ tumours showed better OS than $\mathrm{ER}+1$ AR- tumours and ER-/AR+ tumours showed worse DFS than ER-/AR- tumours on both univariate and multivariate analysis. Other studies too have found that breast cancers with discordant ER/AR expressions (ER+/AR- or ER-/AR+) demonstrated a worse prognosis in comparison to breast cancers with concordant expression (ER + AR+ or ER-/AR -) in multivariable models [33]. As discussed above AR signaling antagonizes the growth stimulatory effects of ER signaling pathways in ER-positive cancers [6]. This may explain why women with ER-positive, ARpositive breast cancers have shown a better prognosis compared to all other AR/ER combinations [33]). It also highlights the importance of stratifying breast cancers according to the ER status when analysing the prognostic value of AR [33].

The implications of AR expression in HER2 amplified $\mathrm{BCa}$ and TNBC is uncertain. Some studies show no effect with AR-positivity [10, 34], some show poorer outcomes $[12,35]$ and others a good prognosis $[7,12]$. AR expression was not associated with prognosis in the HER2 and TNBC IHC molecular subgroups of tumours 

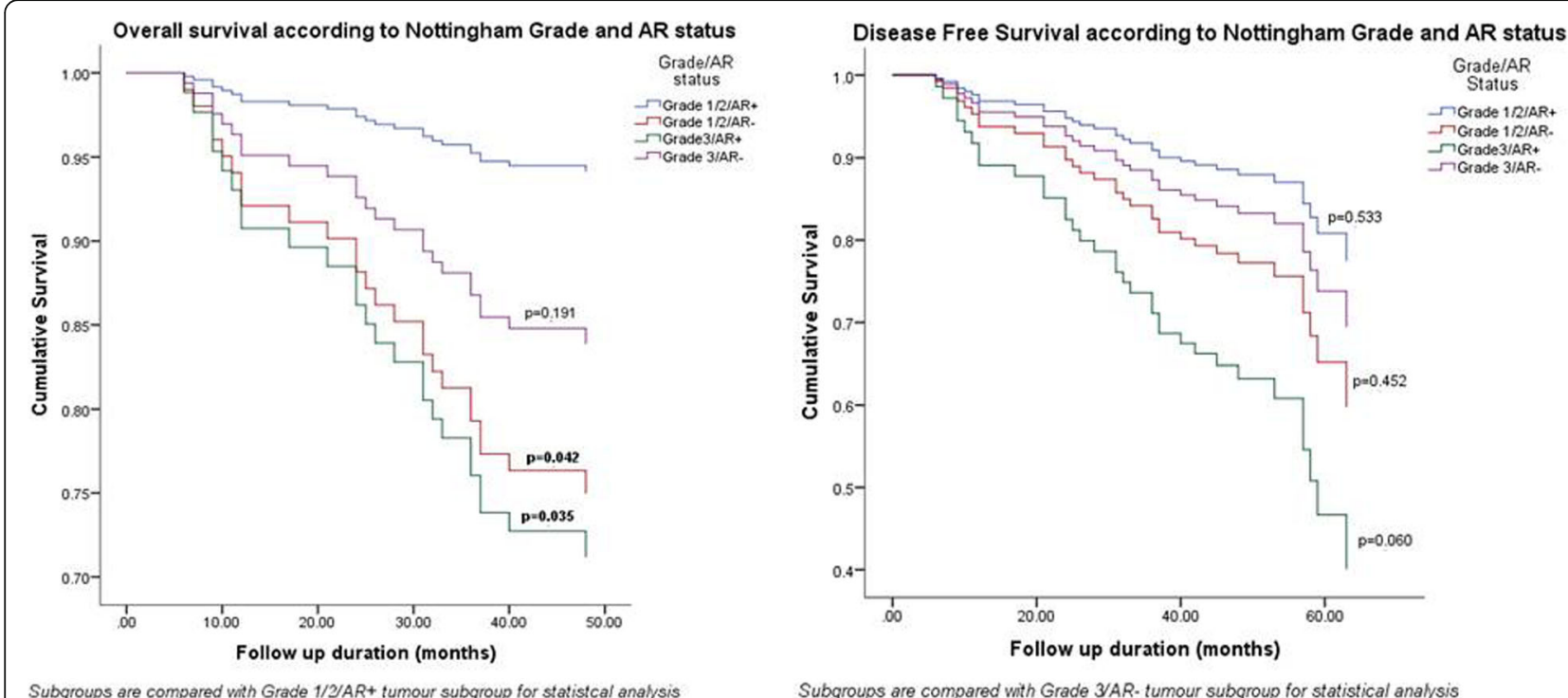

Subgroups are compared with Grade 1/2/AR+ tumour subgroup for statistcal analysis

Subgroups are compared with Grade 3/AR-tumour subgroup for statistical analysis

Fig. 3 Impact of tumour grade and AR status on overall disease free survival according to tumour grade

in this study. However this may be due to the small numbers in these subgroups.

None of the patients studied had been treated with AR agonists or antagonists. Therefore the predictive value of AR status on treatment was not studied. The small sample size in the current study is a limitation. The power of the study is low due to the small sample size. The effects being investigated are also small. These factors increase the likelihood of both false negative and false positive results. This has to be taken into consideration in the interpretation of the results. Additionally the effect of adjuvant therapy also needs to be considered when assessing the impact on prognosis.

However despite these limitations, the finding that AR positivity was associated with a better prognosis in ER positive tumours, especially in postmenopausal women is in keeping with other studies. AR positivity was associated with poorer outcomes in ER negative tumours. These findings are supportive of the use of androgen agonists in ER+/AR+ tumours and AR antagonists in ER $-/ A R+$ tumours $[6,11]$. Large studies have provided conflicting evidence on the prognostic impact of AR

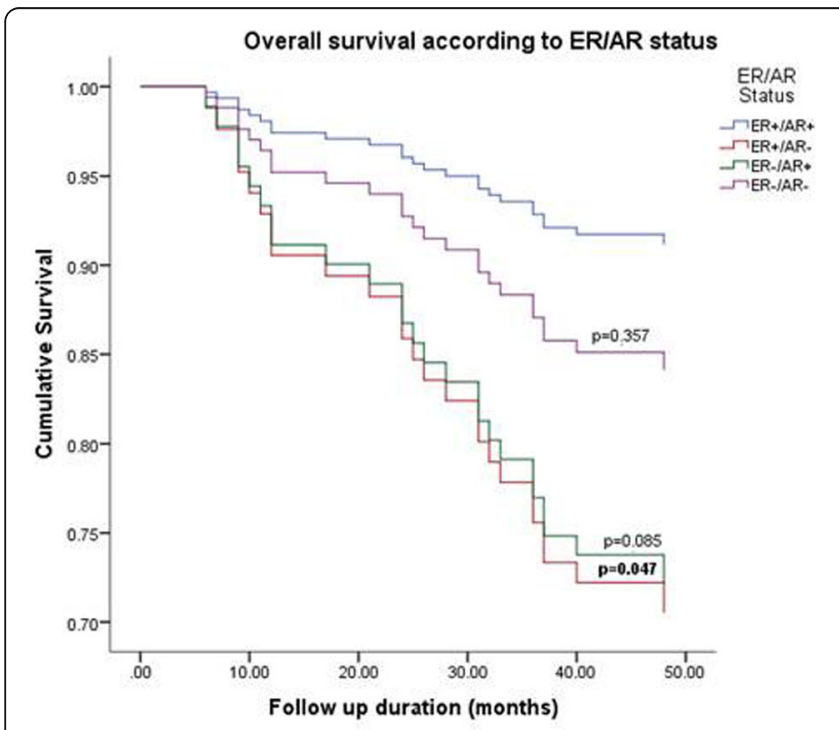

Subgroups are compared with $E R+/ A R+$ tumour sub group for statistical analysis

Fig. 4 Impact of ER/AR status on overall and disease free survival

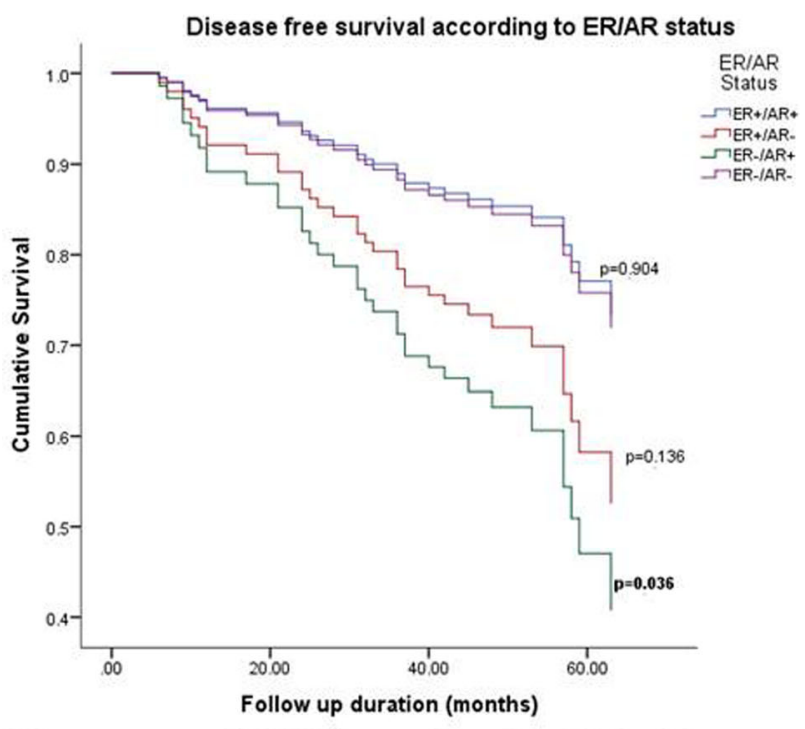

Subgroups are compared with ER-AR-tumour subgroup for statistical analysis 
Table 6 Multivariate Cox regression analysis of factors affecting overall survival

\begin{tabular}{|c|c|c|c|}
\hline Prognostic factor & $p$-value & Hazard ratio & 95\% Confidence intervals \\
\hline Age & 0.115 & 1.036 & $0.991-1.083$ \\
\hline TNM Stage & $<0.001$ & & \\
\hline Stage I vs Stage III & 0.011 & 0.062 & $0.007-0.534$ \\
\hline Stage II vs Stage III & $<0.001$ & 0.154 & $0.058-0.409$ \\
\hline Nottingham grade & 0.360 & & \\
\hline Grade 2 vs Grade 1 & 0.164 & 0.447 & $0.144-1.388$ \\
\hline Grade 3 vs Grade 1 & 0.637 & 0.766 & $0.253-2.319$ \\
\hline Margin involvement (Involved vs Uninvolved) & 0.578 & 1.430 & $0.405-5.052$ \\
\hline Molecular subtype & 0.396 & & \\
\hline HER 2 vs Luminal & 0.456 & 0.505 & $0.084-3.042$ \\
\hline TNBC vs Luminal & 0.509 & 1.624 & $0.386-6.833$ \\
\hline ER/AR Status & 0.051 & & \\
\hline ER+/AR- vs ER+/AR+ & 0.015 & 5.500 & $1.395-21.685$ \\
\hline ER-/AR+ vs ER+/AR+ & 0.050 & 5.049 & $1.001-25.457$ \\
\hline ER-/AR- vs ER+/AR+ & 0.345 & 2.256 & $0.417-12.207$ \\
\hline
\end{tabular}

status in early breast carcinoma, particularly in postmenopausal women [10,32]. This is the first study on AR expression in breast carcinoma in Sri Lanka and despite the limitations, these findings add to the evidence that AR positivity is a widespread aspect of breast cancer that deserves therapeutic attention and further study.

\section{Conclusions}

The histological and IHC molecular tumour characteristics of this $\mathrm{BCa}$ patient cohort from Sri Lanka, were mostly similar to the findings from other regions of the world including Europe and United States of America [26, 28, 36, 37]. The prevalence of AR positivity was lower than most studies in Europe and America which may be a result of regional differences in tumour biology. AR positivity was associated with ER and PR positivity and the IHC luminal subtype. The prognostic effect of AR was dependent on ER expression, with concordant ER/AR expression being predictive of better OS and DFS. AR positivity was associated with a better prognosis among women with ER-positive tumors, especially in the postmenopausal age group.

Table 7 Multivariate Cox regression analysis of factors affecting disease free survival

\begin{tabular}{|c|c|c|c|}
\hline Prognostic factor & $p$-value & Hazard ratio & 95\% Confidence intervals \\
\hline Age & 0.466 & 1.013 & $0.979-1.048$ \\
\hline TNM Stage & $<0.001$ & & \\
\hline Stage I vs Stage III & 0.007 & 0.114 & $0.024-0.550$ \\
\hline Stage II vs Stage III & $<0.001$ & 0.181 & $0.077-0.427$ \\
\hline Nottingham grade & 0.358 & & \\
\hline Grade 2 vs Grade 1 & 0.193 & 0.518 & $0.193-1.394$ \\
\hline Grade 3 vs Grade 1 & 0.773 & 0.862 & $0.313-2.371$ \\
\hline Margin involvement (Involved vs Uninvolved) & 0.970 & 0.976 & $0.281-3.385$ \\
\hline Molecular subtype & 0.283 & & \\
\hline HER 2 vs Luminal & 0.700 & 0.732 & $0.149-3.589$ \\
\hline TNBC vs Luminal & 0.282 & 2.090 & $0.545-8.012$ \\
\hline ER/AR Status & 0.023 & & \\
\hline$E R+/ A R+v s$ ER-/AR- & 0.792 & 1.214 & $0.288-5.107$ \\
\hline ER+/AR- vs ER-/AR- & 0.079 & 3.308 & $0.870-12.580$ \\
\hline ER-/AR+ vs ER-/AR- & 0.014 & 3.537 & $1.286-9.730$ \\
\hline
\end{tabular}


Currently, where the androgen receptor (AR) is emerging as a new biomarker and a potential new therapeutic target in the treatment of $\mathrm{BCa}$ [11], the study findings may have prognostic and therapeutic implications for treatment protocols including androgen receptor agonists or antagonists in appropriate clinical settings.

\section{Abbreviations}

AR: Androgen Receptor; BCa: Breast Carcinoma; Cl: Confidence Interval; DCIS: Ductal Carcinoma in situ; DFS: Disease Free Survival; ER: Oestrogen Receptor; hpf: High power field; IHC: Immunohistochemical; mpf: Medium power field; OS: Overall Survival; PR: Progesterone Receptor; TNBC: Triple negative breast carcinoma

\section{Acknowledgements}

Not applicable.

\section{Authors' contributions}

The study was conceived by MDS and the study design planned by MDS, HW, SV, JF and GKW. Literature review was by SV, ZM and HW. Clinical and follow up data were collected by HW, SV and ZM. The treatment and follow up data was reviewed by DG. Preparation of histological and immunohistochemical slides was by GKW. Interpretation of histology and immunohistochemistry was by HW, JF and MDL. Data entry was by HW, ZM and SV. Data analysis and interpretation was by HW and ZM. The manuscript was drafted by HW, SV, GW and ZM and revised by MDS. All authors have approved the final manuscript.

\section{Funding}

This study was funded by the Kumi and Heram Bilmoria Trust Fund and National Research Council of Sri Lanka Grant 11:51

\section{Availability of data and materials}

The datasets generated and analyzed during the current study are not publicly available since explicit consent for data publication was not obtained from participants at the time of the study and multiple indirect identifiers are included in the data base. However it could be made available from the corresponding author on reasonable request.

\section{Ethics approval and consent to participate}

Ethical approval was obtained from the Ethical Review Committee of the Faculty of Medicine, University of Colombo (EC-17-088). Verbal consent was obtained from all participants and this was approved by the Ethics Review Committee.

\section{Consent for publication}

Not applicable.

\section{Competing interests}

There are no financial and non-financial competing interests to declare.

\section{Author details}

'Department of Pathology, Faculty of Medicine, University of Colombo, Colombo, Sri Lanka. ${ }^{2}$ Department of Pathology, National of Hospital of Sri Lanka, Colombo, Sri Lanka. ${ }^{3}$ Apeksha Hospital, Maharagama, Sri Lanka.

Received: 30 March 2019 Accepted: 3 September 2020

Published online: 14 September 2020

\section{References}

1. National Cancer Control Programme Cancer incidence data: Sri Lanka year 2010. National cancer control programme. 2016. https://nccp.health.gov.lk/ images/PDF_PUBLICATIONS/Cancer_Incidence_Data_2010.pdf. Accessed 26 Jan 2019

2. Tang P, Tse GM. Immunohistochemical surrogates for molecular classification of breast carcinoma: a 2015 update. Arch Pathol Lab Med. 2016. https://doi.org/10.5858/arpa.2015-0133-RA

3. Goldhirsch A, Winer EP, Coates AS, Gelber RD, Piccart-Gebhart M, Thürlimann $\mathrm{B}$, et al. Personalizing the treatment of women with early breast cancer: highlights of the St Gallen international expert consensus on the primary therapy of early breast cancer 2013. Ann Oncol. 2013. https://doi. org/10.1093/annonc/mdt303.

4. Haque R, Ahmed SA, Inzhakova G, Shi J, Avila C, Polikoff J, et al. Impact of breast cancer subtypes and treatment on survival: an analysis spanning two decades. Cancer Epidemiol Biomark Prev. 2012. https://doi.org/10.1158/ 1055-9965.EPI-12-0474.

5. lacopetta D, Rechoum Y, Fuqua SA. The role of androgen receptor in breast cancer. Drug Discov Today Dis Mech. 2012. https://doi.org/10.1016/j.ddmec. 2012.11.003.

6. Pietri E, Conteduca V, Andreis D, Massa I, Melegari E, Sarti S, et al. Androgen receptor signaling pathways as a target for breast cancer treatment. Endocr Relat Cancer. 2016. https://doi.org/10.1530/ERC-16-0190.

7. He J, Peng R, Yuan Z, Wang S, Peng J, Lin G, et al. Prognostic value of androgen receptor expression in operable triple-negative breast cancer: a retrospective analysis based on a tissue microarray. Med Oncol. 2012. https://doi.org/10.1007/s12032-011-9832-0.

8. Peters AA, Buchanan G, Ricciardelli C, Bianco-Miotto T, Centenera MM, Harris $J M$, et al. Androgen receptor inhibits estrogen receptor-alpha activity and is prognostic in breast cancer. Cancer Res. 2009. https://doi.org/10.1158/00085472.CAN-09-0452.

9. Caellano I, Allia E, Accortanzo V, Vandone AM, Chiusa L, Arisio R, Durando A et al. Androgen receptor expression is a significant prognostic factor in estrogen receptor positive breast cancers. Breast Cancer Res Treat. 2010. https://doi.org/10.1007/s10549-010-0761-y.

10. Hu R, Dawood S, Holmes MD, Collins LC, Schnitt SJ, Cole K, et al. Androgen receptor expression and breast cancer survival in postmenopausal women. Clin Cancer Res. 2011. https://doi.org/10.1158/1078-0432.CCR-10-2021.

11. Giovannelli P, Di Donato M, Galasso G, Zazzo ED, Bilancio A, Migliaccio A, et al. The androgen receptor in breast cancer. Frontiers in Endocr. 2018. https://doi.org/10.3389/fendo.2018.00492.

12. Bozovic-Spasojevic I, Zardavas D, Brohée S, Ameye L, Fumagalli D, Aedes F, et al. The prognostic role of androgen receptor in patients with early-stage breast cancer: a meta-analysis of clinical and gene expression data. Clin Cancer. 2017. https://doi.org/10.1158/1078-0432.CCR-16-0979.

13. Vera-Badillo FE, Templeton AJ, de Gouveia P, Diaz-Padilla I, Bedard PL, AlMubarak $M$, et al. Androgen receptor expression and outcomes in early breast cancer: a systematic review and meta-analysis. J Natl Cancer Inst. 2014. https://doi.org/10.1093/jnci/djt319.

14. Payandeh M, Shazad B, Madani S, Ramezani M, Sadhegi M. Androgen receptor expression and its correlation with other risk factors in triple negative breast cancers: a report from Western Iran. Asian Pac J Cancer Prev. 2016;17:3321-4.

15. Anand A, Singh KR, Kumar S, Husain N, Kushwaha JK, Sonkar AA. Androgen receptor expression in an Indian breast cancer cohort with relation to molecular subtypes and response to neoadjuvant chemotherapy - a prospective clinical study. Breast Care (Basel). 2017. https://doi.org/10.1159/ 000458433

16. Chottanapund $S$, Van Duursen MBM, Ratchaworapong $K$, Navasumrit $P$, Ruchirawat M, Van de Berg M, et al. Androgen receptor expression in Thai breast cancer patients. Med Sci Basel. 2016. https://doi.org/10.3390/ medsci4030015.

17. Qi JP, Yang YL, Zhu H, Wang J, Ying J, Liu N, et al. Expression of the androgen receptor and its correlation with molecular subtypes in 980 Chinese breast cancer patients. Breast Cancer: basic and. Clin Res. 2012. https://doi.org/10.4137/BCBCR.S8323.

18. Union for International Cancer Control. Early stage breast cancer. 2014 review of cancer medicines on the WHO list of essential medicines. 2014. https://www.who.int/selection_medicines/committees/expert/20/ applications/EarlyStageBreast.pdf?ua=1/24/10/19. Accessed 21 July 2020.

19. Ellis IO, Al-Sam S, Anderson N, Carder P, Deb R, Girling A, et al. Pathology reporting of breast disease is surgical excision specimens incorporating the dataset for histological reporting of breast cancer. London: The Royal College of Pathologists; 2016. https://www.rcpath.org/uploads/assets/7763 be1c-d330-40e8-95d08f955752792a/G148 BreastDataset-hires-Jun16.pdf. Accessed 24 Mar 2019

20. Lakhani SR, Ellis IO, Schnitt SJ, Tan PH, van de Vijver MJ, editors. WHO classification of tumours of the breast. 4th ed. Lyon: International Agency for Research on Cancer; 2012.

21. Elston CW, Ellis $1 \mathrm{O}$. Pathological prognostic factors in breast cancer :experience from a large study with long term follow up. Histopathology. 1991;19:403-10. 
22. Hammond MEH, Hayes DF, Dowsett M, Allred DC, Hagerty KL, Badve S, et al. American Society of Clinical Oncology/College of American Pathologists guideline recommendations for immunohistochemical testing of estrogen and progesterone receptors in breast cancer. Arch Pathol Lab Med. 2010; 134:e48-72.

23. Wolff AC, Hammond MEH, Hicks DG, Dowsett M, MCShane LM, Allison KH, et al. Recommendations for human epidermal growth factor receptor 2 testing in breast cancer: American Society of Clinical Oncology/College of American Pathologists Clinical Practice Guideline Update. J Clin Oncol. 2013. https://doi.org/10.1200/JCO.2013.50.9984.

24. Atkins D, Reiffen KA, Tegtmeier CL, Winther H, Bonato MS, Storkel S. Immunohistochemical detection of EGFR in paraffin-embedded tumor tissues: variation in staining intensity due to choice of fixative and storage time of tissue sections. J Histochem Cytochem. 2004. https://doi.org/10. 1369/jhc.3A6195.2004.

25. Khatcheressian JL, Hurley P, Bantug E, Esserman LJ, Grunfield E, Halberg F, et al. Breast cancer follow-up and management after primary treatment: American Society of Clinical Oncology clinical practice guideline update. J Clin Oncol. 2013. https://doi.org/10.1200/JCO.2012.45.9859.

26. Agrawal A, Ziolkowski P, Grzebieniak Z, Jelen M, Bobinski P, Agrawal S. Expression of androgen receptor in estrogen receptor-positive breast cancer. Appl Immunohistochem Mol Morphol. 2016. https://doi.org/10.1097/ PAl.0000000000000234.

27. Samaka RM, Younes SF. Androgen receptor expression in breast carcinoma of Egyptian patients. J Clin Diagn Res. 2016. https://doi.org/10.7860/JCDR/ 2016/23364.8919.

28. Collins LC, Cole KS, Marotti JD, Hu R, Schnitt SJ, Tamimi RM. Androgen receptor expression in breast cancer in relation to molecular phenotype: results from the Nurses' health study. Mod Pathol. 2011. https://doi.org/10. 1038/modpathol.2011.54.

29. Park S, Koo J, Park HS, Kim JH, Choi SY, Lee JH, et al. Expression of androgen receptors in primary breast Cancer. Ann Oncol. 2010. https://doi.org/10. 1093/annonc/mdp510

30. Rakha E, Reis-Filho JS. Basal - like breast carcinoma: from expression profilin to routing practice. Arch Patholo Lab Med. 2009;133:860-8.

31. Chia K, O'Brien M, Brown M, Lim E. Targeting the androgen receptor in breast cancer. Curr Oncol Rep. 2015. https://doi.org/10.1007/s11912-0140427-8.

32. Kensler KH, Regan MM, Heng YJ, Baker GM, Pyle ME, Schinitt SJ, et al. Prognostic and predictive value of androgen receptor expression in postmenopausal women with estrogen receptor-positive breast cancer: results from the breast international group trial 1-98. Breast Cancer Res. 2019. https://doi.org/10.1186/s13058-019-1118-z.

33. Elebro K, Borgquist S, Simonsson M, Markkula A, Jirstrom K, Ingvar C, et al. Combined androgen and estrogen receptor status in breast cancer: treatment prediction and prognosis in a population-based prospective cohort. Clin Cancer Res. 2015. https://doi.org/10.1158/1078-0432.CCR-142564.

34. Agoff SN, Swanson PE, Linden H, Hawes SE, Lawton TJ. Androgen receptor expression in estrogen receptor-negative breast cancer. Immunohistochemical, clinical, and prognostic associations. Am J Clin Pathol. 2003. https://doi.org/10.1309/42F0-0D0D-JD0J-5EDT.

35. Rakha EA, El-Sayed ME, Green AR, Lee AH, Robertson JF, Ellis IO. Prognostic markers in triple-negative breast cancer. Cancer. 2007;109:25-32. https://doi. org/10.1002/cncr.22381.

36. Gonzalez LO, Corte MD, Vazquez J, Junquera S, Sanchez R, Alvarez AC, et al. Androgen receptor expression in breast cancer: relationship with clinicopathological characteristics of the tumors, prognosis, and expression of metalloproteases and their inhibitors. BMC Cancer. 2008. https://doi.org/ 10.1186/1471-2407-8-149

37. Niemeier LA, Dabbs DJ, Beriwal S, Striebel JM, Bhargava R. Androgen receptor in breast cancer: expression in estrogen receptor-positive tumors and in estrogen receptor-negative tumors with apocrine differentiation. Mod Pathol. 2010. https://doi.org/10.1038/modpathol.2009.159.

\section{Publisher's Note}

Springer Nature remains neutral with regard to jurisdictional claims in published maps and institutional affiliations.

\section{Ready to submit your research? Choose BMC and benefit from}

- fast, convenient online submission

- thorough peer review by experienced researchers in your field

- rapid publication on acceptance

- support for research data, including large and complex data types

- gold Open Access which fosters wider collaboration and increased citations

- maximum visibility for your research: over $100 \mathrm{M}$ website views per year

At BMC, research is always in progress.

Learn more biomedcentral.com/submissions 